\title{
O REINOCENTRISMO DE JESUS COMO CHAVE PARA UMA CRISTOLOGIA NO PLURALISMO RELIGIOSO
}

\author{
The Kingdom of God Jesus as key to a \\ Christology in religious pluralism
}

\author{
Adriano Sousa Lima*
}

\section{RESUMO}

Este artigo resume a dissertação de mestrado do autor, sobre o tema "O Reinocentrismo de Jesus como chave para uma cristologia no pluralismo religioso". Buscamos averiguar em que medida o Reino de Deus pode ser uma chave hermenêutica em favor de uma cristologia no pluralismo religioso. Para fundamentar essa questão, percorremos, através de uma análise bibliográfica, o pensamento de alguns teólogos da área sistemática, bem como teólogos da área bíblica. Na primeira parte, apresentamos o conceito de cultura, desenvolvemos a ideia da diversidade cultural, inclusive no Brasil, e afirmamos o pluralismo como fator cultural. No segundo momento, a partir da reflexão sobre a virada hermenêutica e a apresentação de alguns paradigmas teológicos, fundamentamos o pluralismo religioso como paradigma da teologia, do qual a reflexão cristã não poderá escapar. Finalmente, na terceira e última parte, o enfoque da categoria Reino de Deus e sua centralidade na vida de Jesus de Nazaré foi fundamental para afirmar a possibilidade de uma cristologia no pluralismo religioso.

Palavras-chave: Reino de Deus. Jesus Cristo. Pluralismo Religioso.

\section{ABSTRACT}

This article summarizes the author's dissertation on the theme of the KingdomCentrism of Jesus as the key to a Christology in religious pluralism. We seek to determine the extent to which the Kingdom of God can be a hermeneutical key

* Doutorando em Teologia na Pontifícia Universidade Católica do Paraná. <adriano. lima.66@hotmail.com>.

\begin{tabular}{|l|l|l|l|l|l|}
\hline Teocomunicação & Porto Alegre & v. 44 & n. 1 & p. 55-77 & jan.-abr. 2014 \\
\hline
\end{tabular}


in favor of a Christology in religious pluralism. To support this point, we have come through a literature analysis, the thinking of some systematic theologians, as well as biblical theologians. In the first part, we present the concept of culture, developed the idea of cultural diversity including Brazil and affirm the pluralism as a cultural factor. In the second moment, from the reflection on the hermeneutic turn and the introduction of some theological paradigms, we founded religious pluralism as a paradigm of theology, which the Christian reflection cannot escape. Finally, the third and final part, the focus of the category Kingdom of God and its centrality in the life of Jesus of Nazareth was essential to affirm the possibility of a Christology in the religious pluralism.

Keywords: Kingdom of God Jesus Christ. Religious. Pluralism.

\section{Introdução}

O pluralismo é uma das características da atual globalização em seus diversos aspectos, inclusive o religioso. Se, em tempos remotos, a questão do pluralismo religioso estava mais ligada a uma ideologia que logo ia passar para nunca mais retornar, no início do século XXI, o pluralismo religioso emerge como novo paradigma da teologia cristã e como tema central da teologia das religiões. Dessa forma, constitui inadiável tarefa a elaboração de uma teologia cristã do pluralismo religioso na sociedade plural.

O cristianismo é desafiado a apresentar uma reflexão teológica nova e criativa nesse momento da história. Não mais poderá descansar à sombra do paradigma tomista. Os problemas da revolução científica, da subjetividade, da história, entre outros, fizeram ruir os alicerces da teologia cristã, confrontando-os com novas questões interpeladoras. Nesse cenário, o cristianismo é convidado a manifestar sua identidade, não para fechar-se sobre si mesmo ou como desculpa para fugir dos desafios que lhe são postos, mas para buscar compreender-se melhor no contexto do pluralismo religioso.

O núcleo cristológico sempre emergiu como o centro das discussões no pluralismo religioso. O presente texto quer colocar-se frente a frente com esse problema e analisar até que ponto a questão cristológica pode ou não ser obstáculo para o diálogo cristão com as outras tradições religiosas. Sem pretensão de esgotar a pesquisa sobre o tema, até mesmo porque isso não é possível, essa reflexão pretende buscar respostas para relevantes perguntas colocadas pelo momento atual. No quadro cultural pluralista em que vivemos, com o grau de conhecimentos que hoje 
temos das demais religiões e de suas implicações culturais, permanece ainda possível sustentar a centralidade de Jesus e do Cristianismo? Pode Jesus de Nazaré ser interpretado de tal forma que as pessoas que foram sustentadas por suas tradições religiosas próprias - Hinduísmo, Budismo, etc. - não precisem interromper suas jornadas espirituais para encontrar Jesus, mas podem encontrá-lo na sua própria jornada? O pluralismo religioso leva o cristão a perder a identidade ou essa afirmação é apenas pressuposto para permanecer no exclusivismo? No entanto, uma nova pergunta que move essa pesquisa é a seguinte: Em que medida o Reino de Deus - categoria central na vida e na mensagem de Jesus - pode ser recuperado como possibilidade para uma cristologia no pluralismo religioso?

\section{O pluralismo como fator cultural}

O antropólogo americano Clifford Geertz sintetiza do seguinte modo a vasta pesquisa de Clyde Kluckhohn sobre o conceito de cultura, realizada mediante 126 diferentes definições: cultura é o modo de vida global de um povo; o legado social que o indivíduo adquire de seu grupo; uma forma de pensar, sentir e acreditar; uma abstração do comportamento; uma teoria, elaborada pelo antropólogo, sobre a forma pela qual um grupo de pessoas se comporta realmente; um celeiro de aprendizagem em comum; um conjunto de orientações padronizadas para os problemas recorrentes; um comportamento aprendido; um mecanismo para a regulamentação normativa do comportamento; um conjunto de técnicas para se ajustar tanto ao ambiente externo como em relação aos outros homens; e uma sedimentação da história. ${ }^{1}$

A cultura é uma totalidade complexa que abrange conhecimento, crença, arte, costume e quaisquer capacidades adquiridas pelos seres humanos como membro da sociedade. ${ }^{2}$ Paulo Suess, que muito se dedicou aos estudos da inculturação, ao definir o conceito "cultura", também afirma que o mesmo envolve a "globalidade da vida e de cada grupo humano". ${ }^{3}$ Miranda, citando Gallagher, recorre a algumas imagens e descreve cultura como um oceano que nos envolve como peixe na água; o ar que respiramos que pode ser puro ou poluído; uma

\footnotetext{
GEERTZ, Clifford. A interpretação das culturas. Rio de Janeiro: LTC, 1989, p. 4.

TYLOR, Edward. Primitive Culture. Londres: Harper Torchbooks, 1871, p. 1.

3 SUESS, Paulo. Cultura e Religião. In: SUESS, Paulo (org.) Cultura e evangelização. São Paulo: Loyola,1991, p. 46.
} 
lente através da qual vemos, sem cairmos na conta de que não é o único modo de ver; um útero, no qual nos sentimos perfeitamente bem, sem saber que existem outros mundos; um menu existencial, já pronto ou à escolha, cada modalidade com seus limites; um parque recreativo de possibilidades, convidando-nos a uma liberdade criativa; um horizonte sempre atual, além do qual não podemos ver. ${ }^{4}$

A antropologia apresenta-nos concepções diversas de culturas. Para alguns antropólogos as culturas são sistemas em permanente adaptação. Geertz entende as culturas como sistemas simbólicos. Para ele, qualquer ação humana e a própria vida da sociedade devem receber orientações extrínsecas, construídas socialmente por meio de símbolos. ${ }^{5}$ LèviStrauss entende as culturas como sistemas estruturais, na medida em que procuram descobrir nelas os princípios mentais responsáveis pela organização do material oferecido pelo mundo físico, princípios estes que seriam comuns às diversas culturas. ${ }^{6}$ Nesse sentido, a antropologia reflete um esforço para entender a diversidade dos povos, sendo a diversidade uma forma de conhecimento. Portanto, entende-se que as variedades de definições não se opõem, mas se completam, possibilitando o pensamento plural. O modelo ideal de sociedade nacional, com suas qualidades e seus defeitos, enfraqueceu-se, por isso, fala-se tanto do pluralismo cultural.

Se, por um lado, é difícil chegar a um consenso sobre a definição do conceito, por outro lado, nas palavras de Azevedo, "é incontornável a necessidade de deixar clara a noção de cultura com a qual se trabalha". ${ }^{7}$ Mas antes de apontar um conceito base, é preciso concordar com Suess e afirmar que o conceito de "cultura" tem a função de descrever as diferenças entre as culturas e não de procurar denominadores comuns. ${ }^{8}$ Portanto, para essa reflexão, será tomado como base o conceito do próprio Marcello de Azevedo, pioneiro nos estudos sobre cultura e que tem um grande número de trabalhos publicados sobre o tema. ${ }^{9}$ Para o autor, cultura é

4 MIRANDA, Mário França de. A inculturação da fé. Um enfoque teológico. p. 46.

5 GEERTZ, Clifford. A interpretação das culturas. p. 56.

6 Cf. LÉVI-STRAUSS, Claude. Antropologia estrutural dois. Rio de Janeiro: Tempo brasileiro, 1976.

7 STRAUSS, Claude. Antropologia estrutural dois, p. 315.

8 SUESS, Paulo. Inculturação: Desafios, caminhos e metas. Revista Eclesiástica Brasileira. REB 49/193, março 1989, p. 81-126.

9 Na obra "Comunidades eclesiais de base e inculturação da fé", Marcello de Azevedo descreve uma densa apresentação do conceito. 
O conjunto de sentidos e significações, de valores e padrões, incorporados e subjacentes aos fenômenos perceptíveis da vida de um grupo social concreto, conjunto que, consciente ou inconsciente, é vivido e assumido pelo grupo como expressão própria de sua realidade humana e passa de geração em geração, conservado assim como foi recebido ou transformado efetiva ou pretensamente pelo próprio grupo. ${ }^{10}$

Mesmo tomando como ponto de partida o conceito de Azevedo (pelo fato de o mesmo estar muito bem elaborado), evidentemente, a presente reflexão não deixará de considerar outras valiosas contribuições, mesmo porque o conceito é bastante amplo, possibilitando um diálogo interdisciplinar. Vale lembrar que, em se tratando do termo "cultura", filosofia, antropologia cultural e social, teologia, história e sociologia estão todas envolvidas. Não obstante, os conceitos não se contradizem, mas se completam e dialogam mutuamente.

\section{Reconhecimento do pluralismo cultural}

Os estudos da antropologia têm demonstrado que a humanidade é única e singular, que cada cultura particular tem seu valor. A ciência antropológica oferece valiosa contribuição, ensinando o aborrecimento ao fanatismo etnocêntrico, quer este proclame a superioridade racial, que alardeie a sua cultura como a única válida. O filósofo Reinholdo Ullmann, em sua antropologia filosófica, afirmou que uma das grandes lições a ser tirada da Antropologia Cultural é uma atitude de complacência com o relativismo cultural. ${ }^{11}$ Evidentemente, esse "relativismo cultural" deverá ser equilibrado e não dogmático.

A atual sociedade é caracterizada pelo pluralismo cultural. Os sociólogos americanos Berger e Luckmann definem o pluralismo como situação na qual existe uma concorrência entre os vários universos simbólicos ou significações globais da realidade e suas respectivas instituições, todas procurando dar sentido e estruturação à vida de cada dia. ${ }^{12}$ Ao contrário das sociedades tradicionais, onde a interpretação

\footnotetext{
${ }^{10}$ LÉVI-STRAUSS, Claude. Antropologia estrutural dois. Rio de Janeiro: Tempo Brasileiro, 1976, p. 336.

${ }^{11}$ Cf. ULLMANN, Reinholdo. Antropologia Filosófica. 2. ed. Porto alegre: EST, 1983.

${ }^{12}$ Cf. BERGER, Peter; LUCKMANN Thomas. Modernidade, pluralismo e crise de sentido: a orientação do homem moderno. 3. ed. Petrópolis - RJ: Vozes, 2012.
} 
global detinha a hegemonia e estruturava a vida social, a sociedade moderna é marcada pela pluralidade de interpretações.

A vida em sociedade, nos seus diversos aspectos, exige um total reconhecimento do pluralismo cultural. No passado, como revela a história, era excluído da convivência social todo aquele que pensava e vivia diferente. Hoje isso não é mais possível. O reconhecimento é a chave hermenêutica para a erradicação dos extremos casos de etnocentrismo que sempre resultaram em conflitos sociais. ${ }^{13}$

Não existe uma cultura completa em todos os seus aspectos. A cultura judaica, islâmica, hindu, confuncionista, africana, indígena e todas as demais são incompletas. Aqui também reside um fator de afirmação do pluralismo cultural. ${ }^{14}$ Tendo consciência da sua incompletude, uma cultura se abre para o diálogo com as outras culturas. É exatamente nessa relação dialogal das culturas que acontece a complementação umas das outras. Portanto, o pluralismo não apenas está estabelecido como fator cultural, mas é critério indispensável para a promoção humana.

É consenso que "não há teologia fora de uma inscrição na história e na cultura". ${ }^{15}$ Portanto, a teologia produzida dentro do contexto de pluralismo cultural não poderá ficar à margem da demanda. Essa demanda deverá ser, por um lado, crítica e criativa e, por outro lado, construtiva e desconstrutiva. Por razões de herança cultural com raízes arcaicas, tem-se a tendência de hierarquizar as diferenças, valorizando uns mais e outros menos. Goffré lembra que o mito de Babel, a diversidade das línguas e, portanto, das culturas, está essencialmente sob o signo da ambiguidade em relação ao desígnio único de Deus. ${ }^{16} \mathrm{O}$ teólogo norteamericano David Tracy chama atenção para o fato de que, "numa cultura historicamente consciente, o fato do pluralismo cultural é reconhecido e afirmado". ${ }^{17}$ Por isso a mensagem de libertação que a teologia cristã propõe deve passar pelo reconhecimento das riquezas culturais que estão além do nosso olhar. É preciso afirmar e reconhecer o pluralismo para que a mensagem do Evangelho seja uma mensagem de vida abundante.

${ }_{13}^{13}$ LARAIA, Roque de Barros. Cultura: um conceito antropológico, p.72-73.

${ }^{14}$ HOFFMAN, Paul. Direito e diversidade. Fórum Social Mundial, p. 63.

${ }^{15}$ GEFFRÉ, Claude. De Babel a Pentecostes: Ensaios de teologia inter-religiosa. Tradução de Margarida Maria Cicchelli Oliva. São Paulo: Paulus, 2013, p. 26.

${ }^{16}$ GEFFRÉ, Claude. Crer e Interpretar. A virada hermenêutica da teologia. Petrópolis RJ: Vozes, 2004, p. 135.

17 TRACY, David. A imaginação analógica - A teologia cristã e a cultura do pluralismo. Tradução de Nélio Schneider. São Leopoldo RS: Unisinos, 2006, p. 150-151. 


\section{O pluralismo como paradigma teológico}

Paradigma, como nos tornou familiar Thomas Kuhn, é um conceito proveniente do mundo das ciências. Um modelo global, a précompreensão segundo a qual se auto-organiza o conjunto. Conforme foi dito anteriormente, o paradigma do pluralismo está operando na cultura em geral, portanto nas religiões, entre elas, o cristianismo e também na teologia. Nesse momento, a presente reflexão quer fundamentar o pluralismo religioso como paradigma da teologia a partir da concepção do teólogo católico Claude Geffré. Este afirmou que "não há teologia fora de uma inscrição na história e na cultura". ${ }^{18}$ Já o teólogo protestante Paul Tillich na última conferência antes da sua morte, em 12 de outubro de 1965, expressou o desejo de reescrever sua Sistemática sob o paradigma do pluralismo religioso.

Em termos epistemológicos, a teologia sofre deslocamentos em sua própria estrutura; é desconstruída e reconstruída no diálogo com seu tempo e lugar cultural. Se, por um lado, as teologias foram questionadas pelo pensamento contemporâneo, por outro lado (no momento atual) se confronta com uma questão mais radical: reinterpretar algumas verdades fundamentais do cristianismo, ${ }^{19}$ como, por exemplo, o caráter central de Cristo, expressão primeira da fé salvadora, questionada pela pluralidade cultural e religiosa.

A teologia deve tomar cada vez mais a sério o horizonte do pluralismo religioso, o retorno religioso e a vitalidade das grandes religiões não cristãs. ${ }^{20}$ A emergência cada vez mais clara do pluralismo, a ponto de se desenhar um novo paradigma, impele uma reflexão, ensaiando nova linguagem. A teologia, elaborada do ponto de vista do paradigma emergente é concretamente uma teologia pluralista libertadora, a partir da perspectiva e da opção pelos pobres. ${ }^{21}$ Para o teólogo francês Claude Geffré as questões da coexistência com as grandes tradições religiosas colocadas ao cristianismo é uma questão quase mais temível que a questão do ateísmo e da indiferença religiosa. ${ }^{22}$

O teólogo brasileiro Faustino Teixeira afirma ser o pluralismo religioso como um fenômeno incontestável da nossa época e um dos

\footnotetext{
18 GEFFRÉ, 2013, p. 27.

19 GEFFRÉ, 2013, p. 133.

${ }^{20}$ GEFFRÉ, 2013, p. 132.

${ }^{21}$ SUSIN, Luiz Carlos. Refletindo o percurso: um clamor e uma luz que vêm de toda parte. Revista Internacional Concilium, n. 319. Petrópolis: Vozes, 2007, p. 8.

22 GEFFRÉ, 2004, p.132.
} 
desafios fundamentais da teologia cristã. Talvez o grande desafio do nosso tempo. Nas palavras de Teixeira, "é uma tarefa difícil, exigente e provocadora". ${ }^{23}$ Por um lado, a responsabilidade da teologia cristã, na era do pluralismo religioso e cultural, é de promover um cristianismo que seja lugar de fecundação mútua e criadora entre os recursos de certa tradição cristã e as riquezas antropológicas; por outro lado, essa mesma teologia, à luz do paradigma pluralista, deverá revisitar os grandes capítulos de toda a dogmática cristã.

\section{O pluralismo religioso como paradigma da teologia no século XXI}

O teólogo dominicano Claude Geffré era muito preocupado com questões de teologia fundamental, e estava consciente de que, em décadas passadas, as questões da descrença moderna e a indiferença religiosa norteavam a produção teológica. No entanto, sob a inspiração de Paul Tillich, Geffré acredita que o pluralismo religioso é o novo paradigma da teologia. ${ }^{24}$ Nas palavras do próprio teólogo:

Como já vimos, não há teologia sem tomar a sério a correlação entre experiência fundamental da primeira comunidade cristã, aquela que se traduziu nos textos fundadores do cristianismo, e nossa experiência histórica como homens e mulheres do século XXI. Ora, nesta experiência histórica, é preciso mencionar como um fato importante a questão do pluralismo religioso. É à luz deste pluralismo religioso que somos convidados a reinterpretar algumas verdades fundamentais do cristianismo. Se podemos falar legitimamente de uma virada hermenêutica da teologia, é em grande parte porque o pluralismo religioso exerce praticamente a função de um novo paradigma teológico. ${ }^{25}$

O paradigma do pluralismo como questão teológica deverá ser o horizonte de toda reflexão sobre Deus, cristologia, eclesiologia e missão. O último concílio (Vaticano II) abriu caminhos fecundos para que a teologia cristã possa aos poucos ser uma teologia relacional, que dialogue de igual modo com outras teologias. O eurocentrismo da

\footnotetext{
${ }^{23}$ TEIXEIRA, Faustino. O pluralismo religioso como novo paradigma para as religiões. Concilium, N. 319. Petrópolis: Vozes, 2007, p. 27.

${ }^{24}$ GEFFRÉ, 2004, p.134.

25 GEFFRÉ, 2004, p. 131.
} 
teologia cristã vem aos poucos dando lugar a uma reflexão policêntrica que pode ser terreno de fecundação mútua. O paradigma emergente do pluralismo religioso busca conscientizar a todos de que não existe uma teologia universal, mas que todas as teologias devem dialogar entre si, tendo como objetivo final a plenitude humana.

O pluralismo religioso está dividido em duas vertentes: o pluralismo de fato e o pluralismo de princípio. A primeira diz respeito à própria pluralidade ou diversidade de tradições religiosas existentes, todas elas. Tal diversidade existe de fato e não pode ser negada. No entanto, a existência desse pluralismo de fato leva o teólogo Claude Geffré a se questionar se "nós não somos convidados a pensar na possibilidade de um pluralismo de princípio que dependeria do próprio desígnio de Deus". ${ }^{26}$

O debate sobre a aceitação definitiva de um pluralismo de princípio diverge opiniões no universo da teologia. Entre os teólogos que defendem essa corrente, é possível encontrar grandes nomes como E. Schillebeeckx, J. Dupuis, M. Amaladoss, Roger Haight e Geffré. Para o teólogo brasileiro Mário de França Miranda, defensor de um pluralismo de fato, esse debate é secundário, visto que as religiões "não estão aí para completar o que faltou em Jesus Cristo, mas sim o que falta em nossa apropriação desta verdade última sobre Deus e sobre nós, que é inevitavelmente contextualizada e histórica". ${ }^{27}$ Geffré faz um questionamento que, devido à sua importância, merece ser referido:

A questão teológica que é preciso ser colocada é de se perguntar se essa vitalidade das religiões não cristãs é simplesmente devida seja à cegueira e ao pecado dos homens, seja a um certo fracasso da missão cristã, ou se esse pluralismo religioso corresponde a um querer misterioso de Deus. ${ }^{28}$

Nas palavras citadas, podem-se observar três questões interessantes: 1) As pessoas que pertencem às outras tradições religiosas são "cegas", limitadas e fechadas à revelação divina? 2) A Igreja cristã, em sua missão, não consegue anunciar o mistério trinitário com competência?;

${ }^{26}$ GEFFRÉ, Claude. Crer e Interpretar. A virada hermenêutica da teologia. Petrópolis RJ: Vozes, 2004, p. 135.

${ }^{27}$ MIRANDA, Mário França de. As religiões na única economia salvífica. Atualidade teológica. Rio de Janeiro. Ano 6. N. 10, jan - abr., 2002.

${ }^{28}$ GEFFRÉ, 2004, p. 135. 
3) Ou o pluralismo religioso é um querer misterioso de Deus, um desígnio de Deus para a humanidade? Apesar de ter consciência de que, no primeiro momento, a Bíblia faz um juízo pessimista sobre as outras religiões, Geffré acredita que a diversidade dos fenômenos religiosos deve ser afirmada à luz de textos neotestamentários. Com base em textos como 1 Tm 2,4, "Deus quer que todos os homens sejam salvos e cheguem ao conhecimento da verdade"; e em At 10, 34-35 "Verifico que Deus não faz acepção de pessoas, mas que, em qualquer nação, quem o teme e pratica justiça lhe é agradável"; Gefré vai optar pela terceira questão e afirmar que "o pluralismo religioso pode ser considerado como um desígnio misterioso de Deus cuja significação última nos escapa". ${ }^{29}$

Os dias atuais são desafiadores para a teologia cristã. Se "a atual crise do cristianismo é em grande parte uma crise de linguagem", ${ }^{30}$ o paradigma do pluralismo religioso não admite linguagens desclassificadoras. É momento de sensibilidade e respeito pelas diversas tradições religiosas, que são caminhos constitutivos de salvação. Conforme Haight,

Em nenhuma outra época as pessoas tiveram tanto senso da diferença dos outros, do pluralismo das sociedades, das culturas e das religiões, bem como da relatividade que isso implica. Já não é possível a centralidade da cultura ocidental, a supremacia de sua perspectiva, ou o cristianismo como a religião superior, ou o Cristo como o centro absoluto em relação ao qual todas as demais mediações históricas são relativas. ${ }^{31}$

O pluralismo religioso é uma questão que a teologia cristã deverá encarar com muita seriedade. Não se trata apenas de "acrescentar um capítulo ao edifício solidamente construído da teologia clássica", ${ }^{32}$ mas assumir o risco de reinterpretações dos principais capítulos da teologia cristã com a finalidade de dialogar com o mundo de hoje, respeitando a consciência autônoma e histórica de cada indivíduo. De acordo com Schillebeeckx, a teologia cristã precisa reconhecer que "a certeza inabalável de que continuamos possuindo a verdade, enquanto os demais estão errados, não é mais uma possibilidade". ${ }^{33}$ Afinal, "a multiplicidade

${ }^{29}$ GEFFRÉ, 2013, p. 52.

${ }^{30}$ MIRANDA, Mário França de. A salvação de Jesus Cristo: a doutrina da graça. São Paulo: Loyola, 2004, p. 12.

${ }^{31}$ HAIGHT, Roger. Jesus, símbolo de Deus. São Paulo: Paulinas, 2003, p. 384-385.

${ }^{32}$ GEFFRÉ, 2013, p. 27.

33 SCHILLEBEECKX, E. apud KNITTER, Paul. Introdução à teologia das religiões. São Paulo: Paulinas, 2008, p. 24. 
de religiões não é um mal que precisa ser removido, mas antes uma riqueza que tem de ser bem-vinda e por todos desfrutada [...] Há mais verdade religiosa em todas as religiões juntas do que em uma religião determinada [...] isso se aplica também ao cristianismo". ${ }^{34}$ Em perfeita sintonia, Geffré afirma que

A pluralidade das religiões, longe de ser um mal que é preciso progressivamente eliminar, pode contribuir para uma manifestação mais perfeita da riqueza multiforme do mistério de Deus. Mas encontramos imediatamente a objeção: será que isso não leva, necessariamente, a relativizar o cristianismo, que tem a pretensão de ser a única religião, visto que ele só tem sentido em relação à manifestação completa e definitiva de Deus em Jesus Cristo? ${ }^{35}$

Para Geffré, a questão posta da manifestação de Deus em Jesus Cristo é de fundamental importância dentro do novo paradigma do pluralismo religioso. Ele critica os vários teólogos que buscam sacrificar o cristocentrismo em detrimento do teocentrismo. Para esse autor, não se pode aderir ao teocentrismo radical que exclui o cristocentrismo. ${ }^{36}$ Mas é cabível a pergunta do outro lado da moeda: é possível produzir teologia a partir do paradigma do pluralismo religioso, abraçado em um cristocentrismo radical que exclui o teocentrismo? Geffré busca uma dialética mais geral e afirma:

Como já sugeri, em vez de apelar para um teocentrismo muito geral, é a partir da própria mensagem cristã, a saber a manifestação de Deus na particularidade histórica de Jesus de Nazaré, que se deve provar caráter não imperialista e necessariamente dialogal do cristianismo. É exatamente porque o cristianismo reivindica, a justo título, ser a religião da revelação final, que nenhum dos diversos cristianismos históricos, depois de vinte séculos, pode pretender definir a essência do cristianismo como religião da revelação última sobre Deus. Estamos, portanto, livres para negar o caráter absoluto do cristianismo como religião histórica. ${ }^{37}$

A opção de Geffré é pelo pluralismo religioso de princípio e não apenas de fato. Ele opta por valorizar todas as tradições religiosas

\footnotetext{
${ }^{34}$ SCHILLEBEECKX, 2008, p. 25.

${ }^{35}$ GEFFRÉ, 2013, p. 73.

${ }^{36}$ GEFFRÉ, 2013, p. 80.

${ }^{37}$ GEFFRÉ, 2013, p. 37.
} 
como estando dentro do misterioso desígnio de Deus. Nessa virada paradigmática, o pluralismo religioso, querido e desejado por Deus, admite que as outras tradições religiosas não são projeções das preparações de uma única verdade. Elas são simplesmente estatuto de uma verdade diferente. E é fundamental que haja por parte da revelação cristã o reconhecimento de que a própria revelação cristã é inadequada em relação à plenitude da verdade última que está unicamente em Deus. ${ }^{38}$ Sem dúvida, não é uma empreitada fácil. Nas palavras de Teixeira, "trata-se de uma tarefa difícil, exigente e provocadora". ${ }^{39}$

\section{O reinocentrismo como chave para uma cristologia no pluralismo religioso}

\section{O Reino de Deus, o centro da mensagem de Jesus}

Jesus viveu toda sua vida em função da sua fidelidade ao Reino de Deus. E morreu por isso. Para ele, a causa do Reino é a causa de Deus que visa ao bem da humanidade. Por isso, deve ficar claro em qualquer cristologia que Jesus não é propriedade exclusiva dos cristãos. Ele não pertence de forma única ao cristianismo. Aliás, está cada vez mais evidente que Jesus atrai muitas pessoas fora dos muros cristãos. Tanto os religiosos como os não religiosos, os que acreditam em Deus como os que não acreditam em nenhuma representação de Deus, são sensibilizados e inspirados por esse Judeu que buscava unicamente o bem das pessoas.

A missão de Jesus, portanto, diz respeito ao Reino e não a si mesmo. Jesus era eminentemente reinocêntrico. Concordamos com o eminente teólogo alemão Karl Rahner quando afirma que "Jesus pregou o Reino de Deus e não a si mesmo". ${ }^{40}$ E ainda, com Kasper, para quem "o centro e o marco da pregação e atividade de Jesus foi o Reino de Deus que se tinha aproximado. O Reino constituía a 'causa' de Jesus". ${ }^{41}$ Esse Jesus está completamente fascinado pela causa do Reino. E Schillebeeckx nos brinda afirmando que Jesus

Procura primeiro o Reino de Deus; todo o resto então se resolverá. $\mathrm{O}$ anúncio de Jesus sobre o reinado de Deus só pensa no bem da

\footnotetext{
${ }^{38}$ GEFFRÉ, 2004, p.147

39 TEIXEIRA, 2007, p. 24-32.

40 RAHNER, Karl. Curso fundamental da fé. Introdução ao conceito de cristianismo. São Paulo: Paulus, 1997, p. 298.

${ }^{41}$ KASPER, Walter. Jesús, el Cristo. Salamanca: Sígueme, 1989, p. 86.
} 
humanidade, e não se refere a si mesmo como segundo assunto da sua própria mensagem; em outras palavras: Jesus não se anunciava a si mesmo, embora se possa e se deva dizer, naturalmente, que cada ser humano, naquilo que se dedica também se faz conhecer em sua própria identidade. ${ }^{42}$

Ainda uma simples, mas importante observação. No campo da exegese bíblica e neotestamentária, o fato é que o recurso válido à crítica histórica acaba levando infalivelmente a um redimensionamento de Jesus Cristo, por algumas razões, tais como: o contexto das afirmações neotestamentárias sobre a sua pessoa e obra, o gênero literário dessas afirmações, a diferença insuperável e a descontinuidade total entre as afirmações do Jesus histórico e a interpretação da sua pessoa feita pela igreja apostólica. Como já dito, a exegese está plenamente convencida de que o Reino de Deus exercia papel central na mensagem de Jesus. Para Dupuis, a Igreja apostólica falsificou a mensagem de Jesus. Foi ela (a Igreja) responsável pela "mudança de paradigma que marcou a passagem de um teocentrismo para um cristocentrismo", e o teólogo belga sugere que "está na hora de inverter a situação, retornando ao teocentrismo". ${ }^{43}$

O Reino de Deus, portanto, está no centro da vida de Jesus. Temos consciência de que o termo é amplo e comporta inúmeras definições. O resumo histórico e uma breve apresentação do termo demonstraram isso. No entanto, para fins metodológicos, vamos tomar como ponto de referência a definição de Reino de Deus, de Edward Schillebeeckx, para quem tal expressão é assim definida:

Reino de Deus é a presença de Deus entre os homens, presença salvífica, ativa e encorajadora, afirmada e acolhida alegremente pelos homens. Presença salvífica oferecida por Deus e livremente afirmada pelos homens, que se torna concretamente visível na justiça e em relações de paz entre homens e povos, no desaparecimento de doenças, injustiças e opressões, em novidade de vida, que expele tudo o que estava morto e era mortal. Reino de Deus é nova relação de conversão (metanoia) do homem a Deus, cujo lado palpável e visível é novo tipo de relações libertadoras entre os homens em vida em comum reconciliada em ambiente natural pacífico. Reino

\footnotetext{
${ }^{42}$ SCHILLEBEECKX, Edward. Jesus, a história de um vivente. São Paulo: Paulus, 2008, p. 141.

${ }^{43}$ DUPUIS, Jacques Dupuis. Rumo a uma teologia do pluralismo religioso, 1999, p. 389.
} 
de Deus é a presença de Deus no mundo, reveladora e portadora de salvação [...] Reino de Deus é 'reino de homens", reino humano, em contraposição aos reinos do mundo, que em Dn 7 são indicados por símbolos de animais como reinos do poder do mais forte. Reino de Deus é a eliminação do doloroso contraste entre governantes e governados (também quando Deus é visto como governante tirânico deste tipo.$^{44}$

Essa preciosa definição do teólogo holandês é a mais completa e muito importante para essa pesquisa. Ele demonstra que o Reino de Deus está profundamente ligado à questão sóciopolítica. Aliás, para Schillebeeckx, a cristologia não pode ter como ponto de referência "um Deus que escraviza o homem". Também a cristologia precisa ter todo cuidado com essa questão. Na edição comemorativa dos 20 anos da revista Concilium, o teólogo Schillebeeckx afirma que é

melhor deixar de crer em Deus, do que acreditar num Deus desumano ou num Deus que mantém o homem na escravidão. Afirmações abstratas como "Jesus é o filho de Deus" ou "somente há salvação no nome de Jesus" não adiantam nada, quando não se manifesta como esta profissão cristã funciona sóciopoliticamente. ${ }^{45}$

Portanto, uma cristologia que pretende manter-se fiel a Jesus de Nazaré não deverá ser fechada dentro das suas próprias categorias dogmáticas, mas dinâmica, como dinâmico é o Reino de Deus. Uma cristologia que pretenda fundamentar-se em Jesus de Nazaré deve antes de qualquer coisa fundamentar-se naquilo que foi a razão da vida e da morte de Jesus: o Reino de Deus. Este Reino, por sua vez, não está preso dentro das paredes religiosas, mas aberto ao mundo, a todos os homens e a todas as mulheres. A cristologia fiel a Jesus de Nazaré e ao seu Reino deverá ser uma cristologia do diálogo com o diferente, do respeito e apreço com as outras tradições religiosas, do acolhimento ao estrangeiro, da promoção e humanização do ser humano. Só uma cristologia descentralizada de si mesma, fundamentada no príncipe da paz, disposta a dialogar com todas as tradições religiosas, a fim de promover a paz, erradicar a fome, as injustiças e as diferenças sociais e religiosas, é capaz de anunciar com eficácia o Evangelho, a Boa Notícia.

\footnotetext{
${ }^{44}$ SCHILLEBEECKX, Edward. A história humana - revelação de Deus. São Paulo: Paulus, 1997, p. 151.

${ }^{45}$ SCHILLEBEECKX, Edward O Evangelho não pode estar sujeito à arbitrariedade. Revista Internacional Concilium, n. 190. Petrópolis: Vozes, 1983, p. 27-32.
} 


\section{Cristologia na perspectiva do pluralismo religioso}

Ao refletir sobre uma cristologia nessa perspectiva, concordamos com Haight que "o pluralismo religioso não precisa ser ameaçador nem para a cristologia nem para a consciência da fé cristã em geral". Esse novo paradigma, "pelo contrário, integra o contexto atual para a reflexão sobre a realidade misteriosa de Jesus Cristo". ${ }^{46}$ A cristologia, sem dúvida, permanece sendo o centro da reflexão teológica. É nessa disciplina teológica onde se cruzam questões fundamentais e decisivas para a fé cristã. Portanto, urge a necessidade de uma reflexão cristológica que leve muito a sério a identidade de Jesus. Conforme a assertiva de Schillebeeckx

Uma cristologia teológica - mesmo nova - não será testemunho eficiente, se não for reflexo teológico do que se torna visível na vida das Igrejas, em oração e em cuidado pelo próximo, como práxis do reino de Deus, como "ortopráxis" cristã. Somente então, também uma reflexão mais profunda sobre a identidade de Jesus se torna realmente fecunda. ${ }^{47}$

Nesse processo de produção de uma "cristologia nova" dentro do atual contexto de pluralismo religioso, será necessário colocar-se diante da questão da universalidade e unicidade de Jesus Cristo. Sem pretensão de esgotar a reflexão, mesmo pela impossibilidade de tal feito, vamos seguir algumas pistas a partir da cristologia trinitária, cristologia narrativa e do "mistério de Cristo".

A cristologia narrativa é uma contribuição para uma cristologia em diálogo com as religiões. Conforme já foi dito, foi retomada com muita força, sobretudo na América Latina, a cristologia narrativa, que parte da dinâmica histórica de Jesus de Nazaré, levando em consideração sua história de vida, sua espiritualidade judaica e seu intenso amor pela causa do Reino. Nessa nova retomada, o foco está na existência humana de Jesus e sua profunda relação com o mistério de Deus. Nesse aspecto, reside a fórmula carinhosa como Jesus se dirigia a Deus. Conforme Jeremias nos fez saber, "Abba" era a fórmula como as crianças chamavam "papai" nos dias de Jesus. A expressão por si demonstra como era forte essa relação de Jesus com Deus. Era um homem profundamente espiritual e de um profundo relacionamento com o seu "papai".

\footnotetext{
${ }^{46}$ HAIGHT, Roger. Jesus, símbolo de Deus. São Paulo: Paulinas, 2003, p. 486.

${ }^{47}$ SCHILLEBEECKX, 2008, p. 646.
} 
A cristologia trinitária é também uma proposta que contribui para uma cristologia em diálogo com as religiões. Sobre essa questão, a pesquisa evoca novamente a contribuição de Jacques Dupuis. Por um lado, Dupuis está bem consciente do problema cristológico imposto com a mudança de paradigma. Ele vê com certa perspicácia o problema cristológico na mudança de paradigma do eclesiocentrismo para o cristocentrismo, pois tal mudança, segundo Dupuis, envolve a centralidade que a Igreja cristã havia atribuído a Jesus Cristo em relação ao papel da própria Igreja. Na virada paradigmática do cristocentrismo para o teocentrismo, reside o problema da mediação constitutiva universal que a fé cristã tem atribuído a Jesus no desígnio salvífico da humanidade. ${ }^{48}$

Dupuis compreende as diversas questões postas pelos teólogos "pluralistas" e dedica uma especial atenção para dialogar com elas a partir de uma cristologia trinitária. Para ele, existem duas questões que precisam ser observadas (embora esta pesquisa opte por destacar apenas uma) dentro do atual debate. Primeiramente, ele vai criticar a afirmação de alguns teólogos que afirmam a impossibilidade de ser cristocêntrico nos dias atuais. Dupuis afirma que essa afirmação precisa de "esclarecimento". Nas suas palavras:

O cristocentrimo e o teocentrismo devem ser realmente contrapostos, como é afirmado, como dois paradigmas contraditórios? Afirmar isso já é por si uma opção teológica e cristológica. $\mathrm{O}$ cristocentrismo da tradição cristã não é, com efeito, contraposto ao teocentrismo. Ele jamais põe Jesus Cristo no lugar de Deus, limitando-se a afirmar que Deus o pôs no centro de seu desígnio salvífico para a humanidade, não como fim, mas como 'caminho' (cf. Jo 14,6), não como meta de toda procura humana de Deus, mas como 'mediador' universal (cf. $1 T$ m 2,5) da sua ação salvífica em relação aos seres humanos. A teologia cristã não se encontra diante do dilema de ser tanto cristocêntrica como teocêntrica: é teocêntrica em seu ser cristocêntrica e vice-versa. ${ }^{49}$

As palavras de Dupuis sugerem certa impossibilidade de ser cristocêntrico sem ser teocêntrico e vice-versa. Essa dialética pode ser sugestiva para uma cristologia que visa dialogar com as outras tradições

\footnotetext{
${ }^{48}$ DUPUIS, Jacques. O cristianismo e as religiões. Do desencontro ao encontro. São Paulo: Loyola, 2004, p. 121.

${ }^{49}$ DUPUIS, 2004, p. 122
} 
religiosas. Sobretudo, o autor deixa claro que "a ação salvífica de Deus atinge de vários modos as pessoas, algumas conscientemente, outras inconscientemente". ${ }^{50}$ Para o teólogo belga, é perfeitamente possível que o cristocentrismo inclusivo se harmonize com o pluralismo teocêntrico, pois, para ele, "são dois componentes complementares de uma única realidade". Por isso Dupuis "busca" um pluralismo inclusivo ou um inclusivismo pluralista. ${ }^{51}$ Para ele, essa busca encontra sua expressão na cristologia trinitária, dando destaque às relações interpessoais entre Jesus e seu "papai”, e entre Jesus e o Espírito que enviará. Para o teólogo (e aqui ele concorda com os teólogos do pluralismo), deve ficar claro que Jesus Cristo não substitui o Pai. ${ }^{52} \mathrm{E}$, da mesma forma que Jesus estava centrado em Deus, assim também deve ser a fé cristã. Em concordância com o paradigma teocêntrico, Dupuis afirma que

Deus - e somente Deus é o mistério absoluto e, como tal, está na origem, no coração e no centro de toda realidade; a realidade humana de Jesus, porém, é criada e, como tal, finita e contingente. Se é verdade que o homem Jesus é o filho de Deus de uma maneira única, é igualmente verdade que Deus está além também de Jesus. Quando se afirma que Jesus se encontra no centro do mistério cristão, isso não deve ser entendido em sentido absoluto, mas na ordem da economia das relações livremente mantidas por Deus com o gênero humano na história. ${ }^{53}$

O teólogo belga toca numa questão importante e essencial para o mistério, remetendo essa pesquisa à reflexão de Felix Wilfred, o qual afirma que

Os sistemas totalizantes de cristologia não nos levam, como muitas vezes se supõe, ao mistério pleno de Jesus Cristo, que permanece sempre maior (cada vez maior). Falando do amor de Cristo, Paulo torna-se contemplativo e maravilha-se com 'a largura e cumprimento e a altura e a profundidade' do amor de Jesus Cristo, que 'ultrapassa o conhecimento' $(E f 3,18)$. Este caráter apofático e incomensurabilidade pedem uma multiplicidade de cristologias, que permanecem todas minúsculas diante do mistério avassalador

\footnotetext{
${ }^{50}$ DUPUIS, 2004, p. 123

${ }^{51}$ DUPUIS, 2004, p. 124

52 DUPUIS, 2004, p. 126

${ }^{53}$ DUPUIS, 2004, p. 127
} 
de que tratam. Todas as cristologias compartilham a mesma sorte; todas elas têm um lugar, mas nenhuma delas pode afirmar ser a explicação última de Jesus Cristo. Em outras palavras, qualquer cristologia precisa ser, no fundo, necessariamente apofática. Há razões suficientes, portanto, para acolher uma pluralidade de cristologias. $^{54}$

Para Wilfred, essa pluralidade de cristologias sempre vai existir. E cada uma tem o seu valor peculiar por ter surgido em determinado contexto e respondido aos diversos questionamentos levantados a partir de horizontes diferentes. A questão do mistério de Jesus Cristo exerce uma importância para o desenvolvimento de uma cristologia apofática. Conforme o autor, abordar esse mistério em um contexto pluralista exige o abandono da ontologia. Ele está convicto de que "não é verdade que a melhor defesa da teologia cristã e especialmente da cristologia está na metafísica". Para ele, as cristologias que se inspiram no pluralismo religioso e, portanto, cristologia em chave pluralista, mantêm vivo e vivificante o mistério de Jesus Cristo, sem precisar recorrer a quaisquer categorias ontológicas". ${ }^{55}$

A reflexão wilfredeana move-se numa direção interessante para essa pesquisa. O autor chama atenção para o fato de que, em situações em que o problema estava mais centrado na questão de como se dá o relacionamento entre Cristo e as demais tradições religiosas, hoje é fundamental colocar a questão de forma diferente. Para ele, "é mais importante conhecer como as pessoas de outras crenças se têm aproximado da pessoa e da mensagem de Cristo em sua jornada espiritual". O autor segue dizendo que "muitas vezes a procura do Cristo faz parte da busca espiritual de nossos vizinhos de outras crenças e mesmo de seu misticismo". ${ }^{56}$ Para fundamentar a sua posição, o autor recorre aos povos do sul da Ásia e diz:

Eu poderia afirmar, sem qualquer exagero, que os povos do sul da Ásia, por exemplo, aprenderam mais profundamente sobre Jesus Cristo da maneira como Mohan Roy, Gandhi e Vivekananda extraíram conclusões éticas da vida e ensino de Jesus, aprenderam

\footnotetext{
${ }^{54}$ WILFRED, Félix. Pluralismo cristológico: algumas reflexões. Revista Internacional Concilium, n. 326. Petrópolis: Vozes, 2008, p. 90-102

55 WILFRED, 2008, p. 94.

56 WILFRED, 2008, p. 94
} 
mais da fé com que Keshab Sem interpretou a pessoa de Jesus e da maneira como o analfabeto místico Ramakrishna o experimentou, do que da fórmula de Calcedônia sobre a essência metafísica de Jesus Cristo, fórmula que está muito afastada da cosmovisão e filosofia desses povos..$^{57}$

Para Wilfred, muitas pessoas não cristãs, ao buscarem Jesus na sua jornada espiritual, têm um encontro real e espiritual com ele. O autor chama atenção para o fato de que não se deve ter uma compreensão "tacanha" de discipulado. Fundamentando-se no episódio em que os discípulos procuravam impedir que alguém continuasse expulsando demônios em nome de Jesus, pois os mesmos não faziam parte do seguimento de Jesus, Wilfred afirma que é preciso apreciar a fé das pessoas de outras tradições religiosas. ${ }^{58}$

Para o autor, a afirmativa de que a fé só atua quando Jesus é entendido como Cristo é terminantemente falsa. Os primeiro seguidores de Jesus, na concepção de Wilfred, encontraram a fé no Jesus da história, na sua vida e nos seus ensinamentos sobre o Reino de Deus. Ao seguir a Jesus e experimentar a sua mensagem, havia uma fé viva e atuante em cada discípulo. $\mathrm{O}$ autor está em concordância com Dupuis no que se refere à possibilidade de se falar em inclusivismo teocêntrico..$^{59} \mathrm{O}$ plano de Deus, o mistério de Cristo e a ação do Espírito Santo têm caráter inclusivo. Por essa razão, o autor afirma a necessidade de colocar as interpretações não cristãs de Jesus no horizonte mais amplo. Para ele, se a teologia cristã admitir que as religiões (todas elas) são lugares onde o mistério do plano de Deus, a Palavra e o Espírito estão atuantes, será possível considerar as interpretações das outras tradições religiosas sobre Jesus bem como um aprofundamento e uma reavaliação da cristologia clássica.

Por fim, o teólogo indiano Michael Amaladoss também afirmou essa dimensão mais ampla do mistério de Cristo, que se expressa na famosa frase "Jesus é o Cristo, mas Cristo é mais que Jesus". A sua reflexão cristológica afirma que a única possibilidade de falar da plenitude de Cristo é quando se incluem todas as manifestações de Deus na história, não apenas as que foram realizadas em Jesus. Sendo assim, só é possível falar da plenitude de Cristo quando se acolhem todas as

\footnotetext{
57 WILFRED, 2008, p. 95.

58 WILFRED, 2008, p. 95.

59 WILFRED, 2008, p. 96.
} 
riquezas que estão presentes em todas as tradições religiosas. ${ }^{60}$ Logo, a partir de uma cristologia em profundo diálogo com as religiões, será possível uma maior, melhor e mais ampla abordagem do mistério de Cristo.

\section{Conclusão}

Ao final dessa reflexão, desejamos afirmar nossa mais profunda intuição teológica sobre a possibilidade de uma cristologia no pluralismo religioso, fundamentada na pessoa e na mensagem de Jesus Cristo. Nessa afirmação, temos plena consciência da universalidade da salvação de Jesus Cristo que, por sua vez, em nada afeta a verdade e a validade presentes em outras tradições religiosas.

Em um mundo cada vez mais marcado pelas desigualdades sociais, pela pobreza, pela opressão social, pela injustiça, e pelos grandes conflitos religiosos, que têm destruído milhões de vidas, a solidariedade e sensibilidade de Jesus de Nazaré deverá nos conduzir rumo ao diálogo com as demais religiões, visando unicamente à erradicação do sofrimento humano e à implantação do Reino de Deus. A cristologia só terá sentido se demonstrar seu interesse pela vida humana aqui nesse mundo. Essa é uma tarefa especificamente de uma cristologia fiel a Jesus de Nazaré, e é exatamente por causa de Jesus e "olhando para Jesus", o centro da mensagem cristã, que estamos habilitados a falar de uma cristologia no pluralismo religioso.

A cristologia pode ser uma disciplina pluralista, pois o próprio Evangelho nos apresenta uma pluralidade de cristologia. Nesse aspecto, a cristologia precisa ser uma disciplina pluralista porque Jesus deve ser interpretado e culturalmente apropriado por comunidades particulares, do mesmo modo como aconteceu por ocasião da formação do Novo Testamento. Portanto, é válida a tese segundo a qual a cristologia no pluralismo religioso não exclui a singularidade do cristianismo, uma vez que o próprio Novo Testamento prescreve uma cristologia no pluralismo religioso.

Em Jesus, na sua vida e mensagem, encontramos o maior exemplo de alguém que não teve medo do pluralismo religioso. Que encarou grandes desafios a fim de dialogar com pessoas de outras tradições

${ }^{60}$ AMALADOSS, M. O pluralismo das religiões e o significado de Cristo. In: TEIXEIRA, F. (Org.). Diálogo de pássaros. São Paulo: Paulinas, 1993, p. 89-110. 
religiosas. Que abriu mão de privilégios e categorias doutrinárias para agir com a misericórdia e o amor. Que renunciou viver a religião do templo porque viu nela ódio e sectarismo. Por essa razão ele optou por ser "desleal" com o próprio grupo para se assentar à mesa com os publicanos, pecadores e prostitutas. É bom lembrar que não se come com qualquer pessoa. Nos dias de Jesus, cada um come com os seus. Jesus é patrimônio da humanidade. Ele é o fundamento do cristianismo. Enviado por Deus como um ser humano para todos os humanos. Ele nasceu, cresceu e morreu por causa da paz, da justiça e do amor. Por causa do Reino de Deus. Por isso, é possível uma cristologia no pluralismo religioso. Uma cristologia reinocêntrica onde o centro de Jesus não é ele mesmo, mas os outros, independente da religião.

\section{Referências}

AMALADOSS, Michael. O pluralismo das religiões e o significado de Cristo. In: TEIXEIRA, Faustino (Org.). Diálogo de pássaros. Edições paulinas, 1993.

AZEVEDO, Marcelo. Comunidades Eclesiais de Base e Inculturação. São Paulo: Loyola, 1986.

BERGER, Peter; LUCKMANN, Thomas. Modernidade, pluralismo e crise de sentido: a orientação do homem moderno. 3. ed. Petrópolis: Vozes, 2012.

DUPUIS, Jacques. Rumo a uma teologia do pluralismo religioso. São Paulo: Paulinas, 1999. 2004.

. O cristianismo e as religiões. Do desencontro ao encontro. São Paulo: Loyola,

FERRARO, Benedito. O desafio da fé cristã num mundo plural. Dominus Iesus: problemas pendentes janelas abertas. In: VIGIL, José Maria (Org.). O atual debate da teologia do pluralismo religioso depois da Dominus Iesus. Livro digitais koinonia, v. 1. 2005.

GEERTZ, Clifford. A interpretação das culturas. Rio de Janeiro: LTC, 1989.

GEFFRÉ, Claude. De Babel a pentecostes: ensaios de teologia inter-religiosa. Tradução de Margarida Maria Cicchelli Oliva. São Paulo: Paulus, 2013.

. Crer e interpretar. A virada hermenêutica da teologia. Petrópolis: Vozes, 2004.

. A crise da identidade cristã na era do pluralismo religioso. Concilium, n. 311, p. 13-28. Petrópolis: Vozes, 2005.

. O destino da fé cristã num mundo de indiferença. Concilium, n. 185, p. 80-107.

Petrópolis: Vozes, 1985. 
HAIGHT, Roger. Jesus, símbolo de Deus. São Paulo: Paulinas, 2003.

KASPER, Walter. Jesús, el Cristo. Salamanca: Sígueme, 1989.

KESSLER, Hans. Cristologia. In: SCHNEIDER, Theodor. Manual de Dogmática. Petrópolis: Vozes, 2008. v. 1.

LACOSTES, Jean-Yves. Dicionário Crítico de Teologia. Tradução Paulo Meneses. São Paulo: Loyola; Paulinas, 2004.

LARAIA, Roque de Barros. O conceito antropológico de cultura. SUESS, Paulo (Org.). Culturas e Evangelização. São Paulo: Edições Loyola, 1991.

LÉVI-STRAUSS, Claude. Antropologia Estrutural dois. Rio de Janeiro: Tempo Brasileiro, 1976.

MIRANDA, Mário França de. As religiões na única economia salvífica. Atualidade teológica. Rio de Janeiro, ano 6, n. 10, jan. 2002.

2004.

. A salvação de Jesus Cristo. A doutrina da graça de Deus. São Paulo: Loyola,

RAHNER, Karl. Curso Fundamental da fé. Introdução ao conceito de cristianismo. São Paulo: Paulus, 1997.

SCHILLEBEECKX, Edward. Jesus, a história de um vivente. São Paulo: Paulus, 2008.

. A história humana-Revelação de Deus. São Paulo: Paulus. 1997.

. O Evangelho não pode estar sujeito à arbitrariedade. Concilium, n. 190, p. 27-32. Petrópolis: Vozes, 1983.

SOBRINO, Jon. Jesus, o libertador. Petrópolis: Vozes, 1994.

SUESS, Paulo. Cultura e Religião. SUESS, Paulo (Org.). Cultura e evangelização. São Paulo: Loyola, 1991.

SUSIN, Luis Carlos. Refletindo o percurso. Um clamor e uma luz que vem de toda parte. Concilium, n. 319 Petrópolis: Vozes, 2007.

TEIXEIRA, Faustino. O pluralismo religioso como novo paradigma para as religiões. Concilium, n. 319. Petrópolis: Vozes, 2007.

TEIXEIRA, Faustino (Org.). Diálogo de pássaros. Paulinas, 1993.

TRACY, David. A imaginação analógica. - A teologia cristã e a cultura do pluralismo. [Tradução de Nélio Schneider]. São Leopoldo: Unisinos, 2006.

. "Projeto X": Retrospectivas e sinais dos tempos. Concilium, n. 190, p. 45-58, Petrópolis: Vozes, 1983.

TYLOR, Edward. Primitive Culture. Londres: Harper Torchbooks, 1871.

ULLMANN, Reinhold. Antropologia Filósofica. 2. ed. Porto Alegre: EST, 1983.

WILFRED, Félix. Tornar-se cristão inter-religiosamente. Concilim, n. 340, p. 61-70. Petrópolis: Vozes, 2011. 
WILFRED, Félix. Pluralismo cristológico. Algumas reflexões. Concilium, n. 326, p. 90-102. Petrópolis: Vozes, 2008.

VIGIL, José Maria. Teologia do pluralismo religioso. Para uma releitura pluralista do cristianismo. São Paulo: Paulus, 2006.

. O paradigma pluralista: tarefas para a teologia. Para uma releitura pluralista do cristianismo. Concilium, n. 319 Petrópolis: Vozes, 2007.

Recebido: 28/04/2014

Avaliado: 30/04/2014 